Irina Troyak

Nowosybirsk

\title{
„Rossicum” - ewolucja pojęcia w nauce rosyjskiej od XIX do XXI wieku*
}

Praktyka studiowania i gromadzenia wydanych w obcych językach książek poświęconych państwu rosyjskiemu istniała w Rosji, zanim pojawiło się samo pojęcie rossicum. W pierwszej połowie XIX wieku historyk, filozof i bibliograf, członek-korespondent Petersburskiej Akademii Nauk Fiodor Pawłowicz Adelung (1768-1843) niejednokrotnie starał się w swoich publikacjach zwrócić uwagę rosyjskich uczonych na bogactwo informacji zawartych w obcojęzycznych publikacjach. W swojej pracy zatytułowanej Kritiko-litieraturnoje obozrienije putieszestwiennikow po Rossii do $1700 \mathrm{~g}$. i ich soczinienij podjął próbę zebrania wiadomości dotyczących terytorium Rosji, przede wszystkim etnograficznych i geograficznych, zaczerpniętych z pism cudzoziemskich podróżników. Praca ta została opublikowana już po śmierci Adelunga w 1846 r. ${ }^{1}$ W 1838 r. rosyjski uczony, archeolog, historyk i słynny bibliograf Aleksandr Dmitrijewicz Czertkow (1789-1858) opublikował pierwszą część katalogu swojego księgozbioru, a w przedmowie do niego poinformował, że w swojej bibliotece zbiera planowo wszystko, co kiedykolwiek zostało napisane o Rosji². Do swojej kolekcji włączał wszelkie materiały, niezależnie od języka, opublikowane zarówno w Rosji, jak i poza jej granicami, przyjmując za jedyne kryterium doboru materiałów - treściowe.

* Praca została zrealizowana dzięki finansowej pomocy Centrum Polsko-Rosyjskiego Dialogu i Porozumienia (stypendium w roku akad. 2014-2015)

1 F. Adelung, Kritisch-literärische Übersicht der Reisenden in Russland bis 1700, deren Berichte bekannt sind, Petersburg - Leipzig 1846, Bd. 1-2; Ф. П. Аделунг, Критико-литературное обозрение путешественников по России до 17002. и их сочинений, cz. 1-2, Москва 1848-1864.

2 А. Д. Чертков, Всеобщая библиотека России, или Каталог книг для изучения нашего отечества во всех отношениях и подробностях, cz. 1, Москва 1838. 
Termin rossica $\mathrm{w}$ rosyjskich pracach poświęconych bibliografii pojawił się w drugiej połowie XIX wieku. Miało to związek z działalnością założonej w 1795 r. w Petersburgu Cesarskiej Biblioteki Publicznej (otwartej dla publiczności w styczniu 1814 r.). Planowano w niej zgromadzić wszystkie książki wydrukowane w Rosji, a także wydane za granicą w języku rosyjskim oraz książki o Rosji w innych językach niż rosyjski. Wszakże pierwotnie nie zakładano stworzenia w strukturze biblioteki specjalnej jednostki, której zadaniem byłoby gromadzenie prac dotyczących Rosji wydanych w obcych językach, ani tworzenia jakichkolwiek drukowanych katalogów tego typu publikacji. W 1849 r. na czele biblioteki stanął baron Modest Andriejewicz Korf (1800-1876) - słynny działacz państwowy, historyk, honorowy członek Petersburskiej Akademii Nauk. Właśnie on, w 1850 r., założył w bibliotece specjalny oddział nazwany „Rossica”, którego zadaniem było gromadzenie dzieł dotyczących Rosji opublikowanych w językach obcych zarówno w samej Rosji, jak i poza jej granicami ${ }^{3}$.

W skład kolekcji Oddziału „Rossica” wchodziły trzy zasadnicze grupy wydawnictw: 1) książki i broszury ze wszystkich dziedzin wiedzy, które odnosiły się do Rosji i wydane zostały w obcych językach za granica; 2) książki, czasopisma, gazety, druki ulotne wydane w Rosji w językach obcych; 3) przekłady dzieł autorów rosyjskich na języki obce (niezależnie od treści). Zamierzano zbierać utwory o Rosji w językach wszystkich narodów europejskich.

W 1873 r. opublikowany został bibliograficzny katalog kolekcji „Rossica”, który obejmował 29391 tytułów ${ }^{4}$. W przedmowie do niego powiedziano, że do zasobów „Rossica” włączane są ,,wszystkie dzieła w językach obcych, które w jakimkolwiek zakresie (historia, geografia, etnografia, historia naturalna, teologia, literatura, medycyna itd.) dotyczą Rosji" ". Jednakże sformułowania tego nie sposób uznać za definitywny zestaw zasad, według których funkcjonował Oddział „Rossica”. Nie wszystko, co zgromadzono na jego półkach, zostało uwzględnione w katalogu. W szczególności wykluczono z niego książki w języku greckim, który zaliczono do języków orientalnych, oraz pozostałe za-

3 История Библиотеки в биографиях ее директоров, 1795-2005, СанктПетербург 2006, s. 108, 150.

${ }_{4}$ Catalogue de la section des Russica ou écrits sur la Russie en langues étrangères, t. 1-2, Petersburg 1873. Katalog przygotował pracownik Cesarskiego Bilioteki Publicznej Karl Fiodorowicz Fetterlein.

5 Н. К. Леликова, Эволючия теоретических представлений о россике, [w:] Беспримерное отделение "Россика": Матер. науч. конф. (14 янв. 2000 г., СанктПетербург), Санкт-Петербург 2000, s. 23. 
pisywane alfabetem innym niż łaciński ${ }^{6}$. Książki drukowane cyrylicą przekazane zostały do działu słowiańskiego, nie weszły zatem w skład kolekcji, tak jak wydania w językach orientalnych, książki po gruzińsku, ormiańsku, tatarsku oraz książki żydowskie ${ }^{7}$. W ten sposób w XIX w. podstawę kolekcji „Rossica” w Cesarskiej Bibliotece Publicznej stanowiły w pierwszej kolejności wydawnictwa w językach zachodnioeuropejskich.

Proces identyfikacji i zbierania materiałów o Rosji w Rosyjskiej Bibliotece Państwowej (w czasach ZSRR Państwowa Biblioteka im. W. I. Lenina) także ma długą historię. Podwaliny zbiorów biblioteki stanowi księgozbiór Muzeum im. Rumiancowa. Na przełomie XVIII i XIX wieku poszukiwaniem dokumentów dotyczących historii Rosji za granicą i pozyskaniem ich do własnej kolekcji zajmował się założyciel muzeum - wybitny działacz państwowy, mecenas i kolekcjoner Nikołaj Pietrowicz Rumiancow (1754-1826). Od lat sześćdziesiątych XIX wieku oryginały i kopie materiałów uznawanych za rossica zaczęły napływać regularnie do muzeum dzięki współpracy z partnerami zagranicznymi. Należy podkreślić, że publikacje w językach obcych ukazujące się na terytorium Rosji, nigdy nie były włączone do zespołu „Rossica” w Rosyjskiej Bibliotece Państwowej ${ }^{8}$.

W ten sposób, analizując praktykę kształtowania kolekcji rossiców w dwóch największych bibliotekach rosyjskich, możemy zrekonstruować sposób funkcjonowania samego terminu oraz jego ewolucję zależną od przemian społeczno-politycznych.

Termin rossica pochodzi od łacińskiego rossicum i oznacza „,coś rosyjskiego” (w sensie: „odnoszące się do państwowości rosyjskiej”). W konsekwencji w pojęciu „rossica” mieści się cała literatura, która z powodu języka lub z powodu treści ma związek z Rosją jako państwem, w jej granicach historycznych ${ }^{9}$. Właśnie $\mathrm{z}$ tego względu jednym z najbardziej skomplikowanych aspektów definicji „rossiców” jest kwestia zakresu terytorialnego, gdyż granice Rosji zmieniały się dość często.

W XIX w. przy uzupełnianiu zasobów Oddziału „Rossica” w Cesarskiej Bibliotece Publicznej uwzględniano publikacje dotyczące wszystkich te-

${ }^{6}$ Д. Д. Шамрай, Коллекиия «Россика» в Публичной библиотеке и проблемы ее собирания и изучения, [w:] Публичная библиотека и культура: Три века истории: Документы, материалы, исследования, Вып. 1, Санкт-Петербург 2006, s. 196.

7 Н. К. Леликова, dz. cyt., s. 21-22.

8 Т. В. Ершова, Проект «Россика»: попытка разработки единой концепции, „Библиотековедение”, 1995, nr 1, s. 94.

9 О. Р. Бородин, К созданию концепции национального фонда экстериорики в России, „Библиотековедение”, 1994, nr 2, s. 60. 
rytoriów mających wówczas związek z Cesarstwem Rosyjskim oraz z narodami zamieszkującymi jego terytorium. Zgodnie z tym do „Rossiców” zaliczano na przykład publikacje o Polsce. Wszystko, co wydawano w Polsce od momentu włączenia jej ziem do Rosji, również uważano za przedmiot gromadzenia Oddziału „Rossica”. Dzieła opublikowane wcześniej, ale poświęcone w całości historii Polski, także zaliczano do „rossiców”, nawet jeżeli ukazały się $\mathrm{w}$ miejscach, które nigdy nie należały do Rosji ${ }^{10}$. W czasach poprzedzających rewolucję w Cesarskiej Bibliotece Publicznej ukształtowało się całkowicie jasne przekonanie, że jako „rossica” należy traktować wszystkie pozycje dotyczące Rosji, opublikowane w obcych językach zarówno w samej Rosji, jak i poza jej granicami.

Po rewolucji październikowej i powstaniu ZSRR terminu ,rossica” zaczęto używać przeważnie w stosunku do okresu przedrewolucyjnego. W tym czasie pojawiło się pojęcie ,sovietica”, którym określano zagraniczne materiały odnoszace się do nowego tworu państwowego, jednak kryteria ich doboru w obu bibliotekach w zasadzie nie uległy zmianie. Trzeba także koniecznie podkreślić, że po 1917 r. praktycznie ustało uzupełnianie kolekcji „Rossica” w Rosyjskiej Bibliotece Publicznej (taką nazwę otrzymała Cesarska Biblioteka Publiczna) - z powodu radykalnego ograniczenia dopływu książek z zagranicy. Kontynuowano je jeszcze do 1930 r., kiedy to zlikwidowano dotychczasowy system oddziałów. Uzupełnienie kolekcji w tym okresie realizowane było głównie dzięki wydaniom obcojęzycznym ukazującym się na terytorium ZSRR ${ }^{11}$. Od 1930 r. wpływ „rossiców” zaczął mieć charakter przypadkowy. Wydawnictwa wpływające do biblioteki otrzymywały sygnatury podstawowego księgozbioru zagranicznego lub księgozbiorów oddziałów specjalistycznych, często pozycje te uznawano za podlegające szczególnej ochronie (co oznaczało daleko idące ograniczenie ich udostępniania). Taka sytuacja trwała aż do okresu ,pieriestrojki”. Dopiero w 1991 r. na mocy decyzji dyrektora Rosyjskiej Biblioteki Narodowej (kolejna nazwa dawnej Cesarskiej Biblioteki Publicznej) wznowiono uzupełnianie „rossiców” oraz wydawnictw rosyjskiej emigracji ${ }^{12}$.

10 Н. К. Леликова, dz. cyt., s. 22.

11 А. В. Лихоманов, Коллекиии «Россика» 150 лет, [w:] Коллекиия «Россика» в Российской начиональной библиотеке: вопросы раскрытия: Научные чтения, посвященные созданию отделения «Россика» (20 сентября 2000 г.), СанктПетербург 2002, s. 8.

${ }_{12}$ М. И. Демидова, Г. Д. Секуторова, Приоритеты комплектования «россики» 6 РНБ, „Библиотечные фонды: проблемы и решения: электронный журнал-препринт: научно-практический журнал по проблемам библиотечного фондоведения", 2005, nr $8,<$ http://www.rba.ru/content/activities/section/12/mag/mag08/5.pdf>. 
Prawie równocześnie z ustaniem wpływu „rossiców” do zbiorów Rosyjskiej Biblioteki Publicznej rozpoczęło się intensywne gromadzenie zbiorów w oddziale „Spec-chran” utworzonym w 1922 r. w Bibliotece Państwowego Muzeum im. Rumiancowa (od 1925 r. Państwowa Biblioteka ZSRR im. Lenina). Tam cenzorzy „Gławlitu”13 odsyłali zagraniczne dokumenty zawierające krytykę Związku Radzieckiego, analizy jego gospodarki i polityki, literaturę emigracyjna. W ten sposób do 1988 r., kiedy „Spec-chran” zakończył swoje działanie, w bibliotece powstał dość duży i różnorodny księgozbiór „,rossiców-sovieticów”, a wydawnictwa przedrewolucyjne najlepiej były reprezentowane w zasobach Rosyjskiej Biblioteki Narodowej ${ }^{14}$.

W 1987 r. w moskiewskiej Rosyjskiej Bibliotece Państwowej została przyjęta, dopracowana i skorygowana, w związku z politycznymi zmianami w kraju, koncepcja gromadzenia „rossiców”. Według niej do „rossiców” zalicza się trzy rodzaje dokumentów: „1) kryterium treściowe - zagraniczne dokumenty dotyczące Rosji i ZSRR; 2) według kryterium autorstwa - utwory oryginalne i tłumaczenia autorów rosyjskich i wychodźców z Rosji, wydane lub przygotowane w postaci rękopisu za granica; 3) kryterium języka - materiały opublikowane za granicą po rosyjsku i w innych językach narodów Rosyjskiej Federacji”'15.

Powstanie na skutek rozpadu Związku Radzieckiego w 1991 r. szeregu niezależnych i suwerennych państw uwarunkowało kolejną korektę zasad, według których poszczególne materiały uznawane są za ,rossica”. W czerwcu 1995 r. w Rosyjskiej Bibliotece Państwowej odbyła się „I wszechrosyjska narada dotycząca problematyki rossiców”. Planowano opracować podczas niej jednolitą koncepcję rejestracji bibliograficznej, kształtowania i wykorzystywania narodowego zasobu „rossiców”. Jednym z postanowień wówczas przyjętych była rekomendacja, aby traktować „rossica” jako „exteriorica”, co w rzeczywistości odpowiadało zasadom uzupełniania Rosyjskiej Biblioteki Państwowej. Do „rossiców” zaliczono druki wydane poza granicami Rosji, ale w jakikolwiek sposób związane z nią. Tak zdefiniowane pojęcie obejmowało trzy główne kategorie materiałów: 1) według kryterium treści - dokumenty zagraniczne dotyczące danego kraju i zamieszkujących go narodów; 2) według kry-

13 Gławlit - Gławnoje Uprawlenije po Diełam Literatury i Izdatielstw - główny organ państwowy odpowiedzialny za cenzurę w ZSRR, istniał w latach 1922-1991 (przyp. red.).

${ }_{14}$ Н. В. Рыжак, История формирования и перспективы работы с фондом «россики» в РГБ, [w:] Румяниевские чтения: тез. докл. и сообщ. науч.-практ. конф. (17-18 aпр. 1997 г.), Москва 1997, s. 14-15.

15 T. В. Ершова, dz. cyt., s. 95. 
terium autorskiego - utwory oryginalne i tłumaczenia autorów danego kraju i wychodźców opublikowane za granica; 3) kryterium językowe - dokumenty w języku (językach) narodowym danego kraju powstałe za granica. Odnośnie do zakresu terytorialnego postanowiono trzymać się zasady historycznych granic państwa rosyjskiego (Cesarstwa, ZSRR, RSFSR lub RF), w zależności od tego, do jakiego okresu historycznego należą rozpatrywane dokumenty ${ }^{16}$. W ten sposób przyjęto jako oficjalna, stosowaną w praktyce bibliotecznej definicję pojęcia „rossica” wypracowaną w Rosyjskiej Bibliotece Państwowej.

Mimo wspomnianych wyżej uściśleń do dzisiaj termin „rossica” pozostaje jednym z najbardziej niejednoznacznych pojęć, zwłaszcza gdy chodzi o jego aspekty narodowościowe lub tematyczne. Dzieje się tak, gdyż aparat terminologiczny - w związku z dość ograniczoną liczbą badań naukowych na ten temat - nie został jeszcze dotychczas opracowany. Równocześnie rola „rossiców”, jako zjawiska z dziedziny kultury, nie mieści się w ramach formalnych kryteriów, które są konieczne dla kształtowania kolekcji bibliotecznych. Zabytki, które je tworza, stanowią ważny czynnik kształtowania ,zewnętrznego" obrazu Rosji, zawierają ocenę jej wartości cywilizacyjnych i osiagnięć, tym samym mają ogromny wpływ na opinię społeczną poza Rosja, jak również determinują charakter międzykulturowej komunikacji, w zależności od epoki i konkretnego podmiotu pozostającego w relacji z Rosją (kraju, narodu, grupy społecznej lub religijnej itd.). Dlatego gdy rozpatrujemy pojęcie ,rossica” w szerokim kontekście humanistycznym, jako fenomen kultury i ważny czynnik kształtowania obrazu Rosji za granica, wydaje się logicznym podział całości zagranicznych dokumentów dotyczących Rosji na segmenty w zależności od miejsca i czasu powstania, formy i treści poszczególnych grup publikacji oraz ze względu na adresata zawartych $\mathrm{w}$ nich informacji ${ }^{17}$.

Koniecznie trzeba także podkreślić, że w Rosji nadal brak jest bieżącej bibliografii druków zaliczanych do kategorii „exteriorica”. Bibliografia narodowa w tym zakresie rozwinęła się wyłącznie jako retrospektywna, co zostało zatwierdzone w regulaminie opracowanym podczas konferencji „Bibliografia narodowa jako forma zachowania pamięci historycznej i kulturowej narodu”, która miała miejsce w Moskwie w 2000 roku. „Rossica" zostały w nim określone jako oddzielny kierunek retrospektywnej bibliografii państwowej lub jako znajdujące się poza jej zakresem. Po-

${ }^{16}$ Н. К. Леликова, dz. cyt., s. 24-26.

17 Д. В. Карнаухов, И. С. Трояк, Польская историческая россика как феномен книжной культуры и фактор политических отношений России и Польши, „Библиосфера”, 2012, nr 3, s. 15. 
twierdzono także rolę Rosyjskiej Biblioteki Narodowej oraz Rosyjskiej Biblioteki Państwowej jako głównych instytucji gromadzących „rossica” oraz tworzących ich bibliografię ${ }^{18}$. Tymczasem $w$ zbiorach wielu centralnych bibliotek dziedzinowych oraz regionalnych bibliotek naukowych i publicznych znajduje się niemało „rossiców” - drukowanych i rękopiśmiennych. Co się tyczy zbudowania wspólnego narodowego zasobu „rossiców” oraz koordynacji na poziomie całego kraju prac związanych $\mathrm{z}$ jego budowaniem i rejestracją bibliograficzna, to próba stworzenia zbiorczego katalogu dokumentów zaliczanych do „rossiców”, którą postulowano na omawianej już wyżej naradzie w 1995 r., do dnia dzisiejszego nie została uwieńczona powodzeniem.

Niemniej zainteresowanie społeczności światowej Rosją i wszystkim, co z nią związane, nie tylko nie wygasa, lecz - zwłaszcza w ostatnich dziesięcioleciach - wzrasta i umacnia się. Świadczy to, że badania naukowe nad „rossicami” jako zjawiskiem kultury stają się jednym z kierunków humanistyki, przed którym otwierają się szerokie perspektywy.

tłum. Zbigniew Olczak

\section{Streszczenie}

\section{„Rossica” - ewolucja pojęcia w nauce rosyjskiej od XIX do XXI wieku}

W artykule dokonano analizy znaczeń jakie nadawano pojęciu „rossica” w rosyjskiej bibliografii i nauce o książce od chwili jego pojawienia się w XIX w. do dnia dzisiejszego. Rekonstrukcja funkcjonowania danego terminu była możliwa dzięki analizie zasad gromadzenia zbiorów kolekcji „rossica”, jakimi kierowano się w dwóch największych bibliotekach kraju - Rosyjskiej Bibliotece Narodowej i Rosyjskiej Bibliotece Państwowej.

Termin „rossica” pojawił się w rosyjskich pracach bibliograficznych w drugiej połowie XIX wieku w związku z powstaniem w Cesarskiej Bibliotece Publicznej w 1850 r. oddziału o tej samej nazwie, w którym gromadzono utwory dotyczące Rosji opublikowane w obcych językach zarówno w samej Rosji, jak i poza jej granicami.

Od lat sześćdziesiątych XIX wieku oryginały oraz kopie materiałów uznanych za „rossica” zaczęły regularnie wpływać do Muzeum im. Rumiancowa, które-

18 А. В. Теплицкая, Россика в федеральных наџиональных библиотеках России, [w:] Румянцевские чтения: материаль науч.-практ. конф. "Память России в книжной культуре» (23-25 апр. 2001 г.), Москва 2001, s. 316. 
go księgozbiór stał się później podwalinami Rosyjskiej Biblioteki Państwowej. Jednak utwory w językach obcych, które opublikowano na terytorium Rosji, nie były przedmiotem gromadzenia kolekcji „rossiców” w Rosyjskiej Bibliotece Państwowej.

Po rewolucji październikowej i utworzeniu ZSRR termin „rossica” zaczą być stosowany przeważnie w stosunku do okresu przedrewolucyjnego. W tych czasach pojawiło się pojęcie „sovietica”, oznaczające materiały zagraniczne odnoszące się do nowego państwa. Jednak kryteria doboru gromadzonych materiałów w obu bibliotekach w istocie pozostały niezmienione.

W wyniku postanowień „Wszechrosyjskiej narady dotyczącej problematyki rossiców” z 1995 r. wydano rekomendację, w myśl której „rossica” utożsamiono $\mathrm{z}$,exterioricami”, tj. od tego momentu zaliczano do nich druki wydane poza granicami Rosji, ale w jakiś sposób z niązwiązane. Mimo to „rossica”, tak jak poprzednio, pozostały jednym z najbardziej niejednoznacznych pojęć stosowanych w rosyjskim bibliotekoznawstwie. Wynika to $\mathrm{z}$ faktu, iż aparat terminologiczny w tym zakresie, na skutek małej liczby publikacji naukowych, jest wciąż niedopracowany.

Słowa kluczowe: rossica - terminologia naukowa - ewolucja pojęć XIX-XX w. - biblioteki rosyjskie.

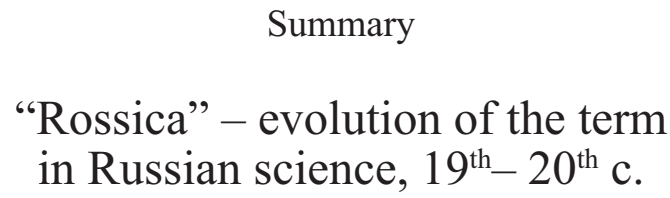

The article analyses the meaning attributed to the term "Rossica" in Russian bibliography and book science, from the moment of its coining in the $19^{\text {th }} \mathrm{c}$. until today. The reconstruction of the changes in its understanding was performed on the basis of the review of the acquisition rules adopted in the "Rossica" collections of the two largest libraries in Russia: the Russian National Library in St. Petersburg and the Russian State Library in Moscow.

The term "Rossica" appeared in Russian bibliographical works during the second half of the $19^{\text {th }} \mathrm{c}$., after a special collection bearing that name was instituted at the Imperial Public Library in St. Petersburg (1850). The "Rossica" collection was supposed to accumulate writings related to Russia, published in foreign languages, both outside of and within Russia.

Since the eighteen-sixties, originals or copies of materials designated as "Rossica" were regularly gathered at the Rumiantsev Museum in Moscow, the library that later on, formed the core of the Russian State Library. But, writings in foreign languages, published within the Russian state borders, were not included into the "Rossica" collection of the Russian State Library. 
After the October Revolution of 1917, the term "Rossica" was predominantly used with respect to publications stemming from the pre-Soviet times. A similar term, "Sovietica" appeared in use, which denoted foreign materials related to the new state. Nevertheless, the criteria of selection in both libraries in question did not change.

In 1995, as a result of the "All-Russian Conference concerning the «Rossica» Issue", a recommendation was published, according to which the "Rossica" were to be considered identical with "exteriorica". This meant that from then on the term "Rossica" encompassed publications related to Russia but printed outside the country. Nevertheless, "Rossica" remains one of the most ambiguous concepts used in Russian library science. This is caused by the fact that Russian bibliographical terminology, due to insufficient number of scientific publications dealing with it, still remains underdeveloped.

Key words: rossica - terminology - evolution of terminology, $19^{\text {th }}-20^{\text {th }}$ c. Russian libraries. 